\title{
A territorial scale-based model for Euroregions and its implications for Cross-Border Cooperation in maritime contexts*
}

\author{
Francesco Maria Camonita \\ Universitat Pompeu Fabra. Barcelona Centre for European Studies (BACES) \\ francescomaria.camonita@upf.edu
}

\author{
Antoni Durà Guimerà \\ Andrea Noferini \\ Universitat Autònoma de Barcelona \\ antoni.dura@uab.cat \\ andrea.noferini@uab.es
}

Received: March 2019
Accepted: July 2019
Published: June 2020

\begin{abstract}
This article attempts to advance the theoretical debate on Euroregions by focusing on their governance structures and the territorial scale of their activities. It develops around a sample of 60 Euroregions and as many corresponding INTERREG projects provided by previous research on Euroregional practices (Durà et al., 2018). Firstly, it elaborates a Euroregional model for the classification of these cross-border governance structures by focusing on $i$ ) a territorial scale-based typology of the cross-border cooperation activities performed and ii) the institutional density and level of self-government of the Euroregional actors involved. Secondly, theoretical contributions are applied in the case of territories mainly focused around maritime borders. By exploiting the results of the research, the article strongly suggests the exploitation of supralocal and regional partnerships alongside employing multilevel Euroregions in cross-sea cooperation.
\end{abstract}

Keywords: cross-border cooperation; Euroregions; Euroregional Model; scales of cooperation; Maritime CBC

* The authors wish to thank the anonymous reviewers for their feedback and suggestions on this article. This work has been funded by an FPI Spanish grant scheme for predoctoral research (BES-2014-068387) associated to the COOP-RECOT II research project (CSO2013-45257-P "Territorial Cooperation in Spain and the EU: A selection of guiding experiences for Excellency and Innovation in the 2014-2020 period"). 
Resum. Un model d'escales territorials per a les euroregions $i$ les seves implicacions per a la cooperació transfronterera en contexts maritims

Aquest article pretén avançar en el debat teòric sobre euroregions a través de l'anàlisi de les seves estructures de governança i de l'escala territorial de les seves activitats. L'argumentació es desenvolupa amb un estudi de seixanta euroregions i d'un nombre corresponent de projectes Interreg seleccionats en investigacions anteriors (Durà et al., 2018). Primer, s'intenta elaborar un model euroregional per a la classificació d'aquestes estructures de governança transfronterera a través d'una tipologia de classificació d'activitats de cooperació transfronterera a escala territorial, i a través de l'anàlisi de la densitat institucional i dels nivells administratius de govern dels actors involucrats. Segon, les contribucions teòriques d'aquest article s'apliquen en el context de territoris separats per una frontera marítima. A partir de l'explotació de resultats, l'article argumenta a favor d'activitats d'escala supralocal i regional al costat d'euroregions de tipus multinivell per a la cooperació transfronterera en contextos marítims.

Paraules clau: cooperació transfronterera; euroregions; model euroregional; escales de cooperació; CTF marítima

Resumen. Un modelo de escalas territoriales para las eurorregiones y sus implicaciones para la cooperación transfronteriza en contextos marítimos

Este artículo pretende avanzar en el debate teórico sobre eurorregiones a través del análisis de sus estructuras de gobernanza y de la escala territorial de sus actividades. La argumentación se desarrolla mediante un estudio de sesenta eurorregiones y de un número correspondiente de proyectos Interreg seleccionados en investigaciones anteriores (Durà et al., 2018). Primero, se intenta elaborar un modelo eurorregional para la clasificación de estas estructuras de gobernanza transfronteriza a través de una tipología de clasificación de actividades de cooperación transfronteriza a escala territorial, y a través del análisis de la densidad institucional y de los niveles administrativos de gobierno de los actores involucrados. Segundo, las contribuciones teóricas de este artículo se aplican en el contexto de territorios separados por una frontera marítima. A partir de la explotación de resultados, el artículo argumenta en favor de actividades de escala supralocal y regional, además de adoptar eurorregiones de tipo multinivel para la cooperación transfronteriza en contextos marítimos.

Palabras clave: cooperación transfronteriza; eurorregiones; modelo eurorregional; escalas de cooperación; CTF marítima

Résumé. Un modèle d'échelles territoriales pour les Eurorégions et ses conséquences pour la Coopération Transfrontalière dans les contextes maritimes

Cet article se donne pour objectif d'avancer dans le débat théorique sur les Eurorégions en mettant l'accent sur leurs structures de gouvernance et sur l'ampleur territoriale de leurs activités. Il se développe autour d'une étude portant sur un échantillon de 60 Eurorégions et autant de projets INTERREG correspondants, fournis par des recherches antérieures sur les pratiques eurorégionales (Durà et al., 2018). En premier lieu, l'article propose un modèle eurorégional pour la classification de ces structures de gouvernance transfrontalières en se concentrant sur : $a$. une typologie à l'échelle territoriale des activités de coopération transfrontalière réalisées, et $b$. la densité institutionnelle et le niveau d'autonomie des acteurs eurorégionaux impliqués. En second lieu, les contributions théoriques sont appliquées au cas de territoires principalement centrés sur les frontières maritimes. En exploitant 
les résultats de la recherche, l'article suggère fortement l'emploi d'activités à une échelle supralocale et régionale, et suggère d'employer des Eurorégions de type multiniveaux dans la coopération transfrontalière maritime.

Mots-clés: coopération transfrontalière; Eurorégions; modèle eurorégional; échelles de coopération; CTF maritime

\author{
Summary \\ 1. Introduction 4. Understanding the different territorial \\ 2. Theoretical framework \\ dynamics of cross-sea cooperation \\ 3. Towards a territorial scale-based \\ 5. Conclusion \\ model for Euroregions \\ Bibliographical references
}

\title{
1. Introduction
}

There has been a growing interest in the field of European Cross-Border Cooperation (CBC) over the last decades. Currently classified as one of the three strands of the European Territorial Cooperation policy of the European Union (EU) (cross-border, transnational and interregional), the cross-border dimension has received attention as an intrinsic tool for subnational authorities pursuing European integration while reducing the separating effects caused by national borders. In this respect, this journal has already produced two monographic issues, Vol. 64(3), 2018 and 56(1), 2010 dealing with CBC and cross-border governance topics.

Following this line of research, our article also attempts to contribute to the debate by focusing on the structure and functions of Euroregions. It achieves its purposes by presenting two main objectives for the research. Firstly, it seeks to provide a general model for the classification of these European cross-border organisations by establishing as explanatory variables: $i$ ) the territorial scale of the $\mathrm{CBC}$ activities performed and ii) the institutional density and level of selfgovernment of the public actors involved. This is done by employing a sample of 60 Euroregions ${ }^{1}$ and a corresponding number of $\mathrm{CBC}$ projects provided by previous research on Euroregional practices during the 2007-2013 EU financial framework (Durà et al., 2018). The analysis includes an innovative classification of CBC activities according to a scale-based typology ('Local, 'Eminently Supralocal' and 'Regional) and a Euroregional model including three variants and six sub-typologies for Euroregional structures (from local 'bilateral Eurocities' to 'multiregional Euroregions').

1. The original sample amounted to 61 units due to the experimental inclusion of the SicilyMalta Cross-Border region in the recount. The implications derived from this research have led us to exclude it from the sample in this article. 
Secondly, this paper represents the continuation of applied research on the maritime border context of the Sicily-Malta Cross-Border Region (Camonita, 2019a, 2019b, forthcoming). Such work paved the way for analysing the $\mathrm{CBC}$ processes of territories across a maritime border ('Eminently Maritime' cross-border regions). The attention towards this geographical context is not incidental. Early on during the creation of the Euroregional sample we had noticed a low presence of Euroregions in the Mediterranean area of Southern Europe. Initially, the presence of maritime spaces seemed to justify the reduced numbers. However, the sample clearly indicated the existence of active CBC experiences across the Baltic Sea. We responded to this issue through dedicated theorisation, while also inquiring into the minor presence of cross-border agreements in sea straits. Through the Sicilian-Maltese example, we developed an operational definition of 'proto-euroregional' territories - understood as border regions developing their $\mathrm{CBC}$ activities through EU programmes but without employing a Euroregional platform - and effectively identified a core of maritime areas that never hosted cross-border institutionalisation (Camonita, 2019b).

In this regard, the proposition of a territorial scale-based typology for $\mathrm{CBC}$ activities and cross-border governance structures is also exploited in the article for understanding the different dynamics of cross-sea cooperation. The main analysis is based on a selection of projects developed in 'proto-euroregional' and 'euroregional' maritime areas (Camonita, 2019b), as well as the governance agreements of the six 'Eminently Maritime' Euroregions in our sample (Durà et al., 2018). Our observations show that, contrary to the presence of all territorial levels across land borders ('Local, 'Eminently Supralocal and 'Regional), the partnerships in maritime areas require a wider number of actors at multiple territorial levels for their activities. This appears evident when noticing the different patterns in local scale $\mathrm{CBC}$ and the absence of exclusively local Euroregional agreements. Therefore, the results lead us to conclude that: a) all scales of activity require partnerships also including supralocal and regional actors and b) that "Eminently Maritime" Euroregions should rely on the multilevel/supralocal variant suggested by our model for increasingly strategic forms of cooperation.

Under this perspective, it is also worth considering the reasons behind the proposition of a Euroregional model. Multiple studies have already acknowledged the great variety of features and institutional backgrounds in Euroregional structures. At the same time, others have attempted to provide explanatory behaviours for these cross-border organisations (see section 2.1). In our view, however, the identification of stronger patterns responds to a need for orientations towards increased Euroregional efficiency; one which is understood as improved performance in a smooth governance system and successful $\mathrm{CBC}$ processes. Thus, the production of results leading to alternative policy suggestions (i.e. the interpretation of the different dynamics of cross-sea cooperation) fits in well with our attempt to provide a model through empirical data and previous theoretical contributions. 
In any case, this line of research already began with the publication of the Euroregional catalogue (Durà et al., 2018). It corresponds to the final output of the COOP-RECOT II research project. ${ }^{2}$ Altogether, the investigation accounted for a comprehensive effort to obtain a bird's eye perspective of Euroregions across Europe. The four years of execution have provided solid theoretical ground on a variety of features such as: an operational definition of Euroregion as a cross-border organisation; two databases showing a compilation of research data; a Euroregional sample representing the most active CBC experiences during the research period; most importantly, a comparative study performed over the sample. Indeed, the research hereby proposed represents a deepening into existing results (i.e. the production of a Euroregional model) as well as a search for new interpretations of data in further territorial backgrounds (i.e. maritime border areas).

Due to all the above, it will be central for this article to answer the following research questions: (1) Is it possible to construct a general model for Euroregions through the observation of existing experiences? (2) What type of Euroregion would better suit a cross-border territory whose activities are mainly focused across a maritime border? To provide evidence, we construct our framework through exploring the theories associated with the two main objectives. Having established our references, the first part of the article is dedicated to a presentation of the territorial scale-based typology and the corresponding Euroregional model. In the second part, we turn to the topic of 'Eminently Maritime' crossborder regions. Accordingly, we will proceed with our discussion on cross-sea $\mathrm{CBC}$ and the suggestion of a supralocal/multilevel variant for Euroregions in maritime contexts. Lastly, we elaborate our conclusion on the whole argument by considering the research prospects inspired in the model.

\section{Theoretical framework}

The first step in our theorisation resides in an adequate understanding of $\mathrm{CBC}$ processes. Due to the institutionalisation of these practices under the EU framework, European CBC can be easily resumed as 'an institutionalised collaboration between contiguous subnational authorities across national borders' (Oliveras et al., 2010: 24). Indeed, this is due to the fact that all INTERREG programmes promoting Territorial Cooperation are mostly managed and exploited by subnational authorities (from small local councils to federated states) belonging to the Union. ${ }^{3}$ The argument is also relevant for understanding the relations between $\mathrm{CBC}$ programmes and Euroregions, especially

2. See the note in the first page of the article for full reference of the project.

3. It should be noted, however, that the definition of 'subnational authority' is often contested. In Belgium, for example, since the federal level and federated entities are on an equal standing, it is inappropriate to refer to regions and communities as "subnational levels" of government. Below the central level, subnational governments are decentralised or deconcentrated public authorities that have (some) responsibilities and (some) degree of autonomy in the provision of (some) public good to a population within a certain territory (OECD, 2010). 
considering that the former does not necessarily imply the presence of the latter (Durà et al., 2018: 24). Indeed, previous contributions have examined border areas inside the EU where the presence of an INTERREG programme does not show a corresponding Euroregional organisation (Camonita, 2019b; Perkmann, 1999). Notwithstanding, this article agrees with prior statements considering that the CBC's 'higher expression is reflected in the creation of cooperation-based organisations, which are in turn oriented towards the coordination of horizontal and vertical policies and joint actions' (Oliveras et al., 2010: 24).

\subsection{The Euroregion: definitions, activities, meaning and classification}

At the time of writing no official definition for the term 'Euroregion' has been universally recognised despite the many institutional and academic attempts to do so. Nevertheless, we indicate the presence of common features across the literature concerned with these organisations.

Two essential definitions. The definition of Euroregions can be essentially grasped through its geographical (territorial) and political (organisational) dimensions. In their simplest conceptualisation, Euroregions can be described as bounded territorial units formed by (at least) two contiguous sub-national units belonging to two separate states (Perkmann, 2002). However, there is a strong association between these geographical areas and their subnational governments which develop joint institutions in the pursuit of common socioeconomic development (Carming et al., 2003). Indeed, from a functional and managerial viewpoint, Euroregions can be seen as associations of subnational authorities across the border seeking to generate an integrated space through specific policies in multiple sectors (Sanguin, 2013: 157; Association of European Border Regions [AEBR], 2000). Contributions from political science have even come to define them as political agreements focused on institutionbuilding processes through public actors' networks and the mobilisation of their institutional capacities (Harguindéguy and Bray, 2009; Morata, 2007; Morata and Noferini, 2013).

The tasks and purposes of a Euroregion. In their classification of the organisational activities of EU cross-border institutions, Miörner et al. (2018) identified four different ranges of activities for policy-network organisations such as the Euroregions. These include $i$ ) the provision of information regarding the regulation of cross-border activities, the promotion of joint activities (i.e. CBC projects) and the organisation of knowledge exchanges; ii) a strong lobbying interest for persuading national institutions towards cross-border issues; iii) incentives for collective sense making through the attraction and distribution of $\mathrm{EU}$ and local funding; and $i v$ ) the promotion of the cross-border area per se (i.e. common identity-building and marketing image) (Miörner et al., 2018: 6-7). Most importantly, it appears evident that Euroregional structures do not represent a new layer of administrative government inside the domain of Member States. Rather, when these Euroregional structures are considered as promot- 
ers of cross-border reterritorialisation - understood as the effective rescaling of social, economic and political activities at the sub-national scale (Popescu, 2008) - they have been somewhat criticised due to their general weakness in such processes. Indeed, Euroregions are usually subject to political compromises in voluntary partnerships and are often constrained by asymmetries between their national administrative and legal systems (Noferini et al., 2020).

The meaning of Euroregional cooperation. Telle (2017) provided an alternative explanation of the utility of Euroregions through his adaptation of the theory of soft spaces. His research elaborates a conceptual distinction between i) hard spaces defined by the boundaries of national politico-administrative units and ii) Euroregions as soft spaces made by the flexible governance arrangements between them. The second ones are indeed considered as deliberate attempts to overcome the impact of national borders. As voluntary agreements, they are allowed considerable freedom to determine their organisational form and agenda. However, the lack of strong political influence and substantial economic funding explains their frequent choice for adaptive strategies and policy niches in their activities. Consequentially, their main objective becomes the achievement of mutual gains through building pragmatic coalitions around certain issues and through existing institutional arrangements (Telle, 2017: 94-98; see also Giband and Vicente, 2018; Faludi, 2013). The argument is equally supported by Perkmann and Spicer (2007), who employ the concept of institutional entrepreneurship to describe the capacity of Euroregions to build organisational competence in cross-border policies. Furthermore, they define the role of Euroregions as specialised implementation units which help in designing INTERREG strategies and sponsoring the consolidation of the CBC projects (2007: 25-26).

Factors allegedly increasing efficiency in Euroregional processes. For the purposes of this article, we focus on two main arguments put forward in the literature: i) the presence of a multilevel governance component in Euroregional partnerships and ii) the alleged effectiveness of Euroregions headed by intermunicipal/supralocal coalitions (which is typical of administrative traditions in Central and Northern Europe). In the first case, we refer to the EU's tendency in a context of globalisation, Europeanisation and decentralisation to shift policymaking towards increasingly plural, open and less hierarchical decision-making from supranational to local level (i.e. Hooghe and Marks, 2001; Piattoni, 2010). Since it is generally understood that CBC involves the implementation of EU programmes through multilevel actors, it should also be assumed that the more layers of governance involved in institutionalised CBC, the more successful it should be (Boman and Berg, 2007; Gualini, 2003). However, this must counterweigh the risks of increasing coordination costs and unstable political commitment in the presence of large partnerships (i.e. Noferini et al., 2020: 8). In the second case, we refer instead to Markus Perkmann's pioneering studies on Euroregions. Through a limited comparative assessment between Northern and Southern European cross-border regions, he showed how Euroregional organisations are more effective in countries 
dominated by administrative traditions granting intermunicipal action. He takes the example of decentralised countries like the Scandinavian states or Germany and compares them to the much more centralised realities of Italy and France. According to the author, the benevolent attitude of Northern European countries towards the implementation of regional policies at the local level strongly contrasted with the suspicion of Southern state authorities, which often fear autonomist or separatist tendencies. Ultimately, the risks associated with ethno-cultural projects led him to question Euroregions which are usually dominated by regional administrations (Perkmann, 2000, 2003, 2005; Perkmann and Spicer, 2007).

Previous applied research and classifications. Due to the multisectoral character of CBC activities, applied research has focused on a variety of fields concerning Euroregional action. To provide some examples, cooperation and euroregional governance across borders have been filtered through the lenses of regional innovation (Lundquist and Trippl, 2013; Trippl, 2010), innovation and tourism (Weidenfeld, 2013), cultural issues (Perrin, 2013), knowledge sharing and triple helix perspectives (Lepik, 2009; Lepik and Krigul, 2014), sustainable development (Morata and Cots, 2006), urban spatial planning (Fricke, 2015) or even public health issues (Glinos and Wismar, 2013).

However, one of the most notable features of Euroregional studies is the scarcity of global comparative analyses of these cross-border organisations. To provide some among the few examples, Perkmann (2003) also attempted to classify Euroregions based on their geographical scope and the intensity of cooperation activities. Other authors have attempted to develop classifications either based on the geographical size of Euroregions in square kilometres (Medeiros, 2011; 2013) or through a typology of their institutional arrangements (Gasparini, 2014). Furthermore, there have been cases of sectoral studies with examples of a specific geographical typology (Decoville et al., 2015), as well as from specific areas of Europe (Gasparini and Del Bianco, 2011). Some encouraging steps towards global perspectives were taken by Wassenberg et al. (2015) through an EU-sponsored publication aiming at classifying all CBC organisations across the continent. More recently, Harguindéguy and Sánchez (2017) attempted to draw up a global list of Euroregions while searching for variables demonstrating their impact on policy activities.

Therefore, it was precisely under this perspective that the Catalogue of Euroregional Good Practices (Durà et al., 2018) tried to provide a more exhaustive outlook on existing Euroregions. The publication included a comparative study on a sample of organisations acknowledged as highly active in their CBC activities. Throughout the analysis, it was possible to provide feedback on various features such as their temporal and geographical distribution across Europe, the diversity of actors and legal instruments employed in their governance or the sectors and modalities of activities developed in their projects (Durà et al., 2019). Notwithstanding, the renewed focus on the territorial scales of $\mathrm{CBC}$ allows us to reengage in the discussion through a reconsideration of the data produced until now. 


\subsection{The concept of Cross-Border Cooperation applied to maritime contexts}

The second part of this article deals with the empirical observation of different dynamics of cross-sea cooperation discovered through a territorial scale-based classification. However, the need for further explanatory references became evident due to the lack of theorisation concerning maritime $\mathrm{CBC}$ in the specialised literature.

At most, the maritime physical dimension of the border is inserted into a larger model seeking to explain multicontextual social constructs through several layers (i.e. legal, economic, political, etc.) (Zimmerbauer, 2011). In a way, it also did not help that $\mathrm{CBC}$ would attract the interest of proponents of maritime spatial planning. The concept has been useful to them for introducing a joint governance dimension in the protection and sustainable development of marine areas (i.e. Carneiro et al., 2017; Schaefer and Barale, 2011). However, in a recent study on the maritime dimension of European CBC programmes, the stakeholders were unanimous in claiming other terrestrial priorities in their activities. The maritime dimension is to them as 'one of several features of the programme geography and only requires some co-operation activities to be related to it' (Hill and Kring, 2013: 8).

Furthermore, maritime $\mathrm{CBC}$ has recently been questioned by the European Commission. As a matter of fact, the European Commission has recently suggested the creation of a special INTERREG programme incorporating maritime cross-border territories and transnational initiatives for the EU operational framework 2021-2027. The proposal has received a heated response from individual authorities and lobbying organisations such as the Conference of Peripheral and Maritime Regions (CPRM), which 'deeply regretted' the decision after exposing multiple flaws in the downsizing of the cross-border dimension (CRPM, 2018: 9-11). Negotiations for the next European budget are still open at the time of writing. Notwithstanding, as stated in a recent briefing report, both the EU Parliament and the Member States' Council seemed inclined to maintain the status quo rather than supporting reform of the INTERREG architecture (Halleux, 2019).

A most relevant contribution to the topic was provided by the Mission Opérationnelle Transfrontalière (MOT), a French agency established for studying territorial cooperation. On its website, it is possible to find a short (and yet significant) topic-study on multisectoral CBC in maritime areas (MOT, 2019). It acknowledges that, contrary to traditional conceptualisations along land borders, the maritime space constitutes a natural barrier creating a territorial separation. However, despite acknowledging increased obstacles in terms of accessibility (time-cost factors for border crossing) and a less-marked cross-border culture, it still recognises a variety of issues upon which CBC can achieve joint potential. These do not only include environmental and sustainable development matters related to marine areas, but also a variety of issues such as employment initiatives, industrial clustering, logistics, tourism and even cultural activities related to historical links. Most importantly, the study recognises three factors associated with the organisation and management of $\mathrm{CBC}$ in maritime spaces: $i$ ) that $\mathrm{CBC}$ for coastal communities is not 
an immediate necessity as in the case of cross-border living areas; ii) consequently, that any long-term strategic project will need political determination from participating authorities; and iii) that the development of governance in maritime $\mathrm{CBC}$ requires multilevel linkages among the different territorial levels affected by the border. The last point is of utmost importance since local, supralocal, regional and national levels all have different administrative powers in relation to maritime competences and towards enacting cooperation through a sea border (MOT, 2019). Indeed, the lack of further contributions to the topic strongly justifies our research.

\section{Towards a territorial scale-based model for Euroregions}

\subsection{A territorial scale-based classification of $C B C$ activities promoted by the $E U$}

Our first hypothesis towards a Euroregional model implied that the territorial scale is capable of affecting both the $\mathrm{CBC}$ activities performed and the governance structure of cross-border organisations. This is why our work begins through the production of a territorial scale-based typology for the categorization of $\mathrm{CBC}$ levels. Initial inspiration was provided by cataloguing efforts of the 60 projects in the Catalogue research (Durà et al., 2018). During our observations, we were led to appreciate the relative freedom of operation in cross-border programmes over the territorial scope of approved projects. This was proved by the funding of a set of initiatives ranging from the development of specific infrastructure on the border to the consolidation of large-scale sectoral networks. Quantitative analysis therefore led us to the idea that the CBC projects could be classified according to a precise territorial scale and through the observation of their effective outcomes. Our first step was to consider the territorial scales defined by effective distance in kilometres from the border as the independent variable. From there, we developed our own typology by focusing on $a$. the territorial scale upon which CBC projects' outputs were supposed to have an impact; $b$. the predominant levels of self-government in the projects' partnerships; $c$. the predominating territorial objectives from each scale according to sectoral activities (environmental protection, socio-economic development, thematic networking and cross-border services and infrastructure). The process led us to identify three separate categories in the classification: 'Local', 'Eminently Supralocal' and 'Regional' CBC activities (see Figure 1 for a schematisation).

Accordingly, the three modalities are described more in detail as follows:

- Type L (Local or 'Proximity Cooperation'). This modality includes CBC activities performed on the border or in its immediate proximity. The activities are usually targeted at environmental protection and/or the socioeconomic development of such territories, or even the development of infrastructure and/or services which help to reduce the border effect of separation across them. Partnerships involved in this kind of activities are usually composed of local and/or supralocal territorial actors, except in the case of cross-border infrastructure not covered by national cooperation 
Figure 1. Graphical schematisation of a scale-based typology for classifying CBC activities
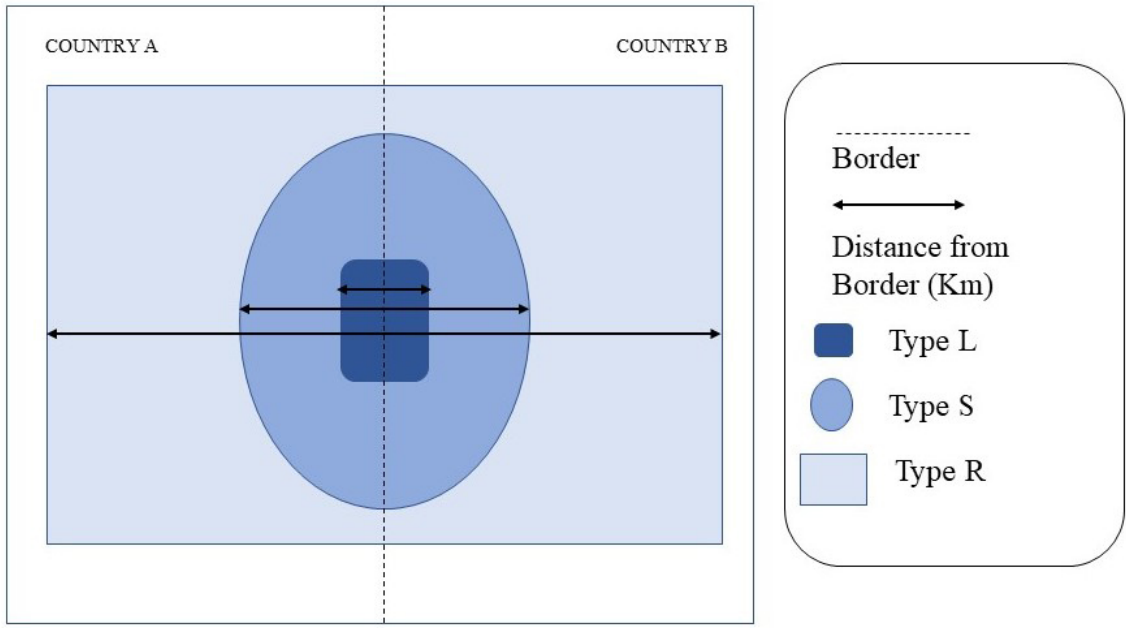

Source: Own elaboration.

treaties and which usually require regional and state-level authorisations (i.e. cross-border hospitals or large-scale tunnels or bridges).

- Type S (Eminently Supralocal or Intermediate Borderlands Cooperation). This type of cooperation involves $\mathrm{CBC}$ activities with a territorial impact aimed at a wider portion of borderlands than the $\mathrm{L}$ type. The activities are also targeted at the protection and/or socioeconomic development of the territories surrounding the border. The term 'Eminently' is willingly employed to indicate the frequent multilevel presence of actors (from the local to the regional sphere) involved in this typology of projects.

- Type R (Regional or 'Interregional Neighbourhood Cooperation'). This refers to $\mathrm{CBC}$ activities involving larger regional territories through the consolidation of wide-scale sectoral networks, at times including partners which are relatively distant from the border. However, all participating actors are still part of a territory involved in a CBC initiative (i.e. INTERREG programme, Euroregional organisation, etc.). Projects included in this typology are more likely to focus on advancements in common knowledge and practices with a looser territorial impact. Their similarity to activities in the transnational and interregional strands of INTERREG suggested a suitable definition for the hybridisation of the cross-border dimension with an interregional project-modality.

After establishing our typology, we tested it through the classification of the $60 \mathrm{CBC}$ projects comprising our sample. The results indicated the presence of 15 Type L, 39 Type $S$ and 6 Type R projects. A few cases are shown in the table below (Table 1). 
Table 1. Example of $\mathrm{CBC}$ projects from the sample classified according to the scale-based typology

\begin{tabular}{|c|c|c|c|}
\hline $\begin{array}{l}\text { CBC Typology } \\
\text { of Activities }\end{array}$ & $\begin{array}{l}\text { Examples of Projects } \\
\text { from CRII Catalogue }\end{array}$ & Euroregion & Details of Activities \\
\hline \multirow[t]{3}{*}{$\begin{array}{l}\text { Local or Proximity } \\
\text { Cooperation (Type L) }\end{array}$} & $\begin{array}{l}\text { Border Place Jacques } \\
\text { Delors }\end{array}$ & $\begin{array}{l}\text { Lille-Kortrijk-Tournai } \\
\text { Eurometropolis }\end{array}$ & $\begin{array}{l}\text { Joint administration of a public square } \\
\text { located on the border between two towns }\end{array}$ \\
\hline & $\begin{array}{l}\text { Bus-Vis-à-Vis to the } \\
\text { Rhine }\end{array}$ & Vis-a-Vis LGTC & $\begin{array}{l}\text { Establishment of a local cross-border bus } \\
\text { service }\end{array}$ \\
\hline & $\begin{array}{l}\text { Thermal and Water } \\
\text { Euroregion }\end{array}$ & Chaves-Verín Eurocity & $\begin{array}{l}\text { Coordinated development of tourism } \\
\text { strategies connected to thermal waters } \\
\text { included in the local area }\end{array}$ \\
\hline \multirow[t]{3}{*}{$\begin{array}{l}\text { Eminently Supralocal } \\
\text { or Intermediate } \\
\text { Borderlands } \\
\text { Cooperation (Type S) }\end{array}$} & $\begin{array}{l}\text { Euregio Bodensee day } \\
\text { pass }\end{array}$ & $\begin{array}{l}\text { International Lake } \\
\text { Constance Conference }\end{array}$ & $\begin{array}{l}\text { Creation of a harmonised public transport } \\
\text { service in the Lake Constance area by } \\
\text { introducing a day pass for local transport } \\
\text { across the border }\end{array}$ \\
\hline & $\begin{array}{l}\text { Emergency response } \\
\text { without borders }\end{array}$ & $\begin{array}{l}\text { Sønderjylland- } \\
\text { Schleswig Euroregion }\end{array}$ & $\begin{array}{l}\text { Common resources in terms of equipment } \\
\text { and personnel for joint coordination and } \\
\text { prevention of risks (i.e. fires, accidents } \\
\text { and natural disasters) }\end{array}$ \\
\hline & $\begin{array}{l}\text { Cross-Border Medical } \\
\text { Cabinet Treatment of } \\
\text { Addiction }\end{array}$ & $\begin{array}{l}\text { Strasbourg-Ortenau } \\
\text { Eurodistrict }\end{array}$ & $\begin{array}{l}\text { Management of a cross-border centre for } \\
\text { drug addictions to provide treatment for the } \\
\text { Euroregional population across the border }\end{array}$ \\
\hline \multirow[t]{3}{*}{$\begin{array}{l}\text { Regional or } \\
\text { Interregional } \\
\text { Neighbourhood } \\
\text { Cooperation (Type R) }\end{array}$} & CREAMED & $\begin{array}{l}\text { Pyrenees-Mediterra- } \\
\text { nean Euroregion }\end{array}$ & $\begin{array}{l}\text { Creation of a Euroregional Network Business } \\
\text { Incubator in order to stimulate innovation, } \\
\text { exchanges and complementarities between } \\
\text { SMEs from the wider Euroregional territory }\end{array}$ \\
\hline & Putting Patients First & CAWT Region & $\begin{array}{l}\text { Delivery of a range of specialist, targeted, } \\
\text { accessible and sustainable cross-border } \\
\text { health and social care services across a } \\
\text { large selection of health-related public and } \\
\text { private actors from the entire Euroregional } \\
\text { territory }\end{array}$ \\
\hline & AdriGov & $\begin{array}{l}\text { Adriatic-Ionian } \\
\text { Euroregion }\end{array}$ & $\begin{array}{l}\text { Activities focused on the development of } \\
\text { governance skills and greater involvement } \\
\text { of local authorities and civil society from the } \\
\text { entire Euroregional territory (decision-mak- } \\
\text { ing processes and implementation of the EU } \\
\text { regional policy) }\end{array}$ \\
\hline
\end{tabular}

Source: Own elaboration.

\subsection{A new model for Euroregions based on the scale of their governance and projects}

The idea that a cross-border governance structure may be associated to a territorial scale was already hinted at through the Euroregional actors' configurations shown in the Catalogue research (Durà et al., 2018: 58-63). In previous analyses, we identified a tendency towards a decreasing number of public actors when increasing the territorial scale of the cross-border territory (2018: 62-63). However, reasoning connected to the scale-based typology in this paper led us 
to further consider i) the territorial level of activities that CBC may want to achieve and ii) the different Euroregional partnerships required for their execution. As a matter of fact, there is a strong correlation between the presence of certain territorial actors in a CBC organisation and the degree of administrative competences entrusted to them by their national constitutions. Although we could assume as 'ideal' the concept of a Euroregion involved at all levels of cooperation (local, supralocal and regional), realistic expectations reveal that the territorial scale of its activities will be highly constrained by the territorial level of actors in the governance agreement. To provide an obvious example, it would be quite unlikely to envision the local councils of two towns at the border dealing with large-scale $\mathrm{R} \& \mathrm{D}$ cooperation networks (Type R).

This is why the Euroregional model is reflected here as both the continuation and the refinement of previous analytical work. On the one hand, it exploits the institutional density (the total number of actors) and the predominant levels of self-government (local, supralocal or regional) of a Euroregion as fundamental factors determining the scale of the governance system in place. On the other, it employs our typology of $\mathrm{CBC}$ activities as a reinforcing argument supporting a classification of Euroregions from a territorial scale-based perspective.

Nevertheless, it should also be mentioned that although multiple alternative variables were considered for inclusion, they were all excluded. For example, we did not find correlations between the selection of the legal formula for regulating cross-border governance (i.e. NGO-type associations, ad-hoc public law agreements or other European instruments) and the partnership involved (Durà et al., 2018: 63-66). Likewise, geographical factors such as the total number of inhabitants of a Euroregion or population density also showed weak correlations with governance variables due to the large variety of contexts encountered (2018: 52-54).

The final design of the Euroregional model can be observed in Table 2. Following the scale-based typology, the model provides three variants for existing Euroregions (Local scale, Supralocal scale and Regional scale). Accordingly, it also provides six sub-typologies developed to better understand the intervals in institutional density and the main levels of self-government. The inclusion of a control variable related to approximate size in square kilometres was also provided to introduce greater clarity in the differentiation. Admittedly, the size intervals provided by the sample lead to considerable variation in the model. However, they provide orientation between Euroregions with different territorial focuses despite coinciding in governance variables. This is clearly demonstrated in the separation between L (2) and S (1)/(2) Euroregion types. Finally, the model is further reinforced by introducing the classification of the 60 Euroregions in the sample and by showing the correlation between the model variants and the classified $\mathrm{CBC}$ projects from the previous section.

Most importantly, the model shows a good potential for classifying existing Euroregional experiences across Europe's internal borders. The L (1) 'bilateral Eurocity' type is well-suited for city twinnings across the border between 
Table 2. Design of a Euroregional model through a territorial scale-based typology

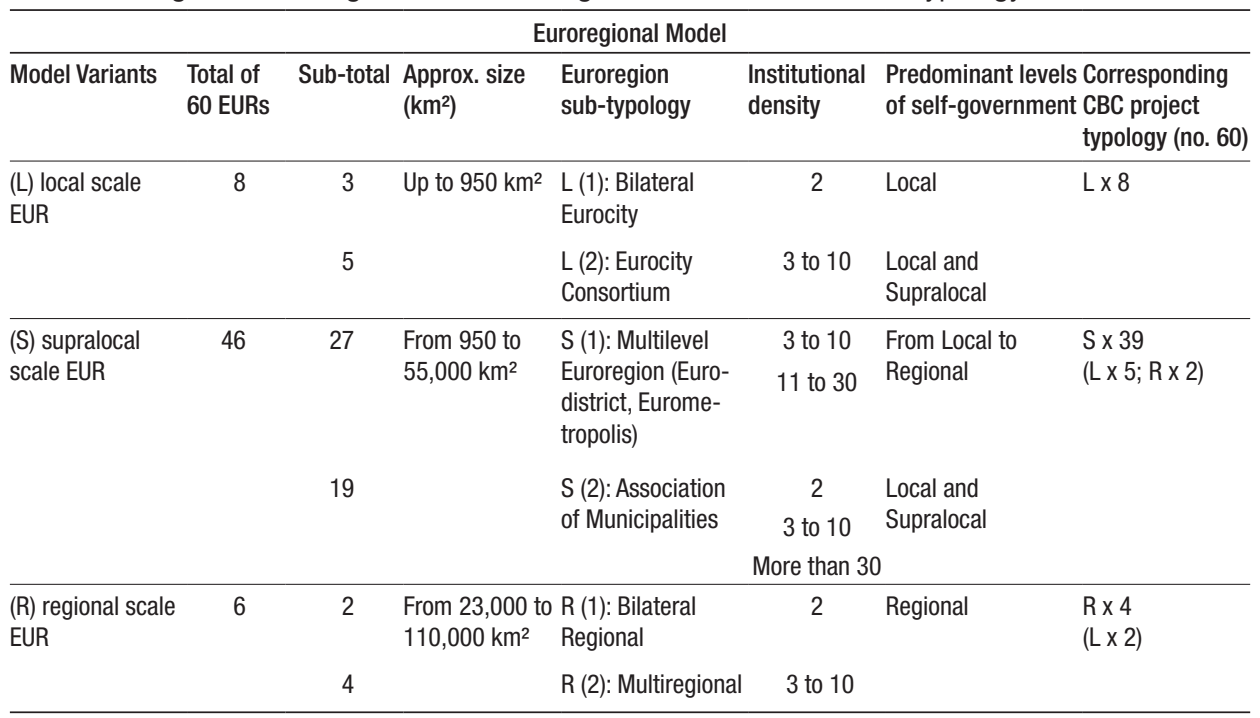

Source: Own elaboration.

local city councils (i.e. Chaves-Verín Eurocity or the Frankfurt (Oder) \& Slubice Cooperative Centre). In contrast, the L (2) 'Eurocity Consortium' refers to other initiatives on a local scale with a more elaborate partnership (multiple local councils or including the participation of supralocal actors, i.e. the Bidasoa-Txingudi Cross-Border Consortium or the Vis-à-vis Local Grouping of Territorial Cooperation). The S (1) 'Multilevel Euroregion' hosts a large number of realities with a smaller (3 to 10 ) and a larger (10 to 30) institutional density. Its dominant feature is deeply multilevel partnerships ranging from local council to regional level administrations. Interestingly, some of the $\mathrm{CBC}$ initiatives included in this grouping also provide alternative marketing brands for defining their Euroregional status (i.e. Strasbourg-Ortenau Eurodistrict, Lille-Kortrijk-Tournai Eurometropolis). The S (2) 'Association of Municipalities' strongly relies on multiple local council memberships, but sometimes the numbers are reduced by the coordinating efforts of supralocal actors in intermunicipal action (i.e. the French Communauté de communes). In turn, this helps to explain the large intervals ranging from bilateral agreements (i.e. Pyrenees-Cerdanya EGTC) to much larger partnerships (i.e. the historical Dutch-German EUREGIO). Finally, R (1) 'bilateral regional' and R (2) 'multiregional' Euroregions are meant to classify cross-border governance exclusively dominated by regional level administrations, whether on a face-toface basis (i.e. Galicia-North Portugal Euroregion) or in a multiple partnership (i.e. Pyrenees-Mediterranean Euroregion).

At this stage, some further clarifications should be considered over the supporting numbers introduced in the model. Firstly, it is important to consider 
Table 3. Observation of 9 cases where CBC project scale-based typology $\neq$ EUR Model Variant

\begin{tabular}{|c|c|c|c|c|c|}
\hline Project Goal & $\begin{array}{c}\text { Typology CBC Project } \neq \\
\text { EUR Model Variant }\end{array}$ & $\begin{array}{l}\text { EUR Model } \\
\text { Variant }\end{array}$ & CBC Project & EUROREGION & Project Budget $(€)$ \\
\hline \multirow[t]{2}{*}{$\begin{array}{l}\text { Accessibility and } \\
\text { Transportation }\end{array}$} & L & $R$ & TransferMuga & $\begin{array}{l}\text { New Aquitaine-Euskadi- } \\
\text { Navarre Euroregion }\end{array}$ & 390,775 \\
\hline & $\mathrm{R}$ & S & Rail Baltica & $\begin{array}{l}\text { FinEst Link (Helsinki- } \\
\text { Tallinn) }\end{array}$ & $3,587,090$ \\
\hline $\begin{array}{l}\text { Education and } \\
\text { Culture }\end{array}$ & $L$ & $R$ & $\begin{array}{l}\text { Portalet's Space } \\
\text { Cooperation Centre } \\
\text { and Border Integration }\end{array}$ & Pourtalet Space EGTC & $1,312,376$ \\
\hline \multirow[t]{2}{*}{$\begin{array}{l}\text { Local Economic } \\
\text { Development }\end{array}$} & L & $S$ & $\begin{array}{l}\text { North West Regional } \\
\text { Science Park }\end{array}$ & $\begin{array}{l}\text { North West Region Cross } \\
\text { Border Group (NWRCBG) }\end{array}$ & $13,859,599$ \\
\hline & L & S & The Innovation Circle & Greater Geneva & $1,050,000$ \\
\hline \multirow[t]{3}{*}{ Spatial Planning } & $L$ & $S$ & $\begin{array}{l}\text { Management and Impro- } \\
\text { vement of Lauterbourg's } \\
\text { former customs building }\end{array}$ & $\begin{array}{l}\text { Regio PAMINA Eurodis- } \\
\text { trict EGTC }\end{array}$ & $1,127,729$ \\
\hline & L & S & $\begin{array}{l}\text { Border Place Jacques } \\
\text { Delors }\end{array}$ & $\begin{array}{l}\text { Lille-Kortrijk-Tournai } \\
\text { Eurometropolis }\end{array}$ & $1,361,085$ \\
\hline & L & S & 3Lands & Basel Trinational District & 700,000 \\
\hline $\begin{array}{l}\text { Research \& } \\
\text { Investigation }\end{array}$ & $\mathrm{R}$ & S & $\begin{array}{l}\text { DISKE: Development } \\
\text { of Innovative Systems } \\
\text { through Knowledge } \\
\text { Exchange }\end{array}$ & Baltic Euroregion & $1,315,311$ \\
\hline
\end{tabular}

Source: Own elaboration.

that the sample employed for the elaboration is a high-quality collection of 60 Euroregional units (and their CBC projects), which were identified according to the operational definitions of excellence and innovation in the Catalogue research. It is the result of a selection out of 158 operating Euroregions showing different levels of activity and identified in the EU's internal borders during the 2007-2013 framework (Durà et al., 2018: 30-35).

Secondly, we understand a priori that the sample shows a strong predominance of Supralocal Scale Euroregions. However, it is important to consider that the Catalogue did not envision the criteria of this research. Indeed, the original results of the Euroregional model show a tendency among the most performing Euroregions to prefer a Supralocal Scale variant in their composition. Furthermore, preliminary observation of the total 158 active units would allow, at best, increasing the number of local variants and to a somewhat lesser degree, the number of regional variants. Nonetheless, it seems that similar distribution rates among the three would prevail.

Thirdly, the introduction of the CBC project classification has proved helpful in confirming the validity of the model variants. A total of 51 out of the 60 projects identified effectively matched the territorial scale proposed for their Euroregion. The remaining 9 projects were interesting exceptions regarding the capacity of Euroregions to partially expand the scope of their activities. 
Figure 2. Map of the six European geographical areas employed in the RECOT sample classification

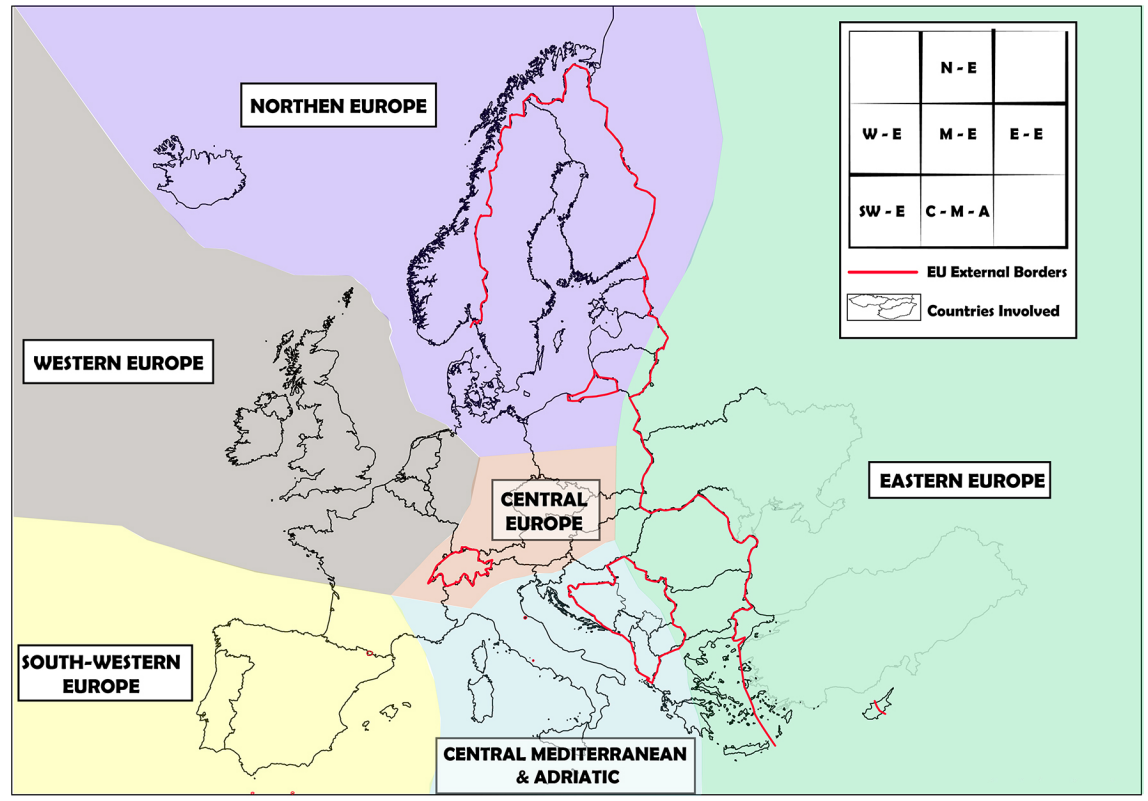

Source: Durà et al. (2018).

Furthermore, in the specific case of L Type projects of the Supralocal Scale variant, it is possible to observe a set of special interventions which seem to require greater involvement from territorial actors beyond local councils. Noteworthy examples include the commitment to create technology and innovation centres (North West Regional Science Park; The Innovation Circle), large infrastructure works of an historical local building (Management and Improvement of Lauterbourg customs building) or even the legal challenges in attempting the cross-border spatial planning of urban areas (Border Place Jacques Delors) (see Table 3). Under such conditions, it may be possible to speculate that for these local interventions the partnerships including supralocal actors would rather dispose of $i$ ) a territorial scale in sufficient proximity to the local area involved (with respect to regional or national level authorities), ii) a wider financial and organisational capacity for mobilising significant amounts of resources and, most importantly, iii) the right amount of administrative competences within their national jurisdictions.

The recurring presence of the Supralocal Scale variant also inspired us to discuss insights from the alleged factors for Euroregional efficiency (see 2.1). By observing the 46 S-Type Euroregions, it is immediately evident that the largest portion of the sample (27/60) employs a S (1) multilevel structure 
including all self-government levels (local, supralocal, regional). This higher preference could confirm previous arguments linking multilevel institutionalisation with better capacity (i.e. Boman and Berg, 2007). In contrast to Perkmann's claims over a limited comparative study (2000; 2003; 2005), Type $S$ (2) Euroregions dominated by intermunicipal action would only rank second as the most employed modality for cross-border governance (19/60).

Furthermore, Perkmann's hypothesis concerning national attitudes towards subnational CBC led us to observe the model variants' concentrations in different parts of Europe. As regards the Catalogue, it already accounted for the classification of six European geographical areas, as it calculated the distribution of the Euroregions included in the sample in these areas $^{4}$ (see Figure 2). After applying the criteria of our Euroregional model, we obtained the data shown in Table 4 below.

Table 4. Distribution of Euroregions in the sample according to the scale-based typology and across six geographical areas of Europe

\begin{tabular}{lcrrrrrr}
\hline $\begin{array}{l}\text { MODEL VARIANT } \\
\text { \& SUB-TYPOLOGY }\end{array}$ & $\begin{array}{c}\text { No. Euroregions } \\
=60\end{array}$ & SWE (9) & WE (16) & CMA (2) & CE (18) & EE (5) & NE (10) \\
\hline L (1): Bilateral Eurocity & $\mathrm{L}(1)=3$ & 1 & 2 & 0 & 0 & 0 & 1 \\
L (2): Eurocity Consortium & $\mathrm{L}(2)=5$ & 2 & 1 & 1 & 0 & 0 & 0 \\
(L) LOCAL SCALE EUR & $\mathrm{L}(1+2)=8$ & 3 & 3 & 1 & 0 & 0 & 1 \\
\% of Total (Approx.) & $100 \%=8$ & $37 \%$ & $37 \%$ & $13 \%$ & $0 \%$ & $0 \%$ & $13 \%$ \\
S (1): Multilevel Euroregion & $\mathrm{S}(1)=27$ & 0 & 8 & 0 & 9 & 3 & 7 \\
S (2): Association of Municipalities & $\mathrm{S}(2)=19$ & 2 & 4 & 0 & 9 & 2 & 2 \\
(S) SUPRALOCAL SCALE EUR & $\mathrm{S}(1+2)=46$ & 2 & 12 & 0 & 18 & 5 & 9 \\
\% of Total (Approx.) & $100 \%=46$ & $4 \%$ & $26 \%$ & $0 \%$ & $39 \%$ & $11 \%$ & $20 \%$ \\
R (1): Bilateral Regional & $\mathrm{R}(1)=2$ & 2 & 0 & 0 & 0 & 0 & 0 \\
R (2): Multiregional & $\mathrm{R}(2)=4$ & 2 & 1 & 1 & 0 & 0 & 0 \\
(R) REGIONAL SCALE EUR & $\mathrm{R}(1+2)=6$ & 4 & 1 & 1 & 0 & 0 & 0 \\
\% of Total (Approx.) & $100 \%=6$ & $66 \%$ & $17 \%$ & $17 \%$ & $0 \%$ & $0 \%$ & $0 \%$ \\
\hline
\end{tabular}

SWE: South-West Europe; WE: Western Europe; CMA: Central Mediterranean and Adriatic; CE: Central Europe; EE: Eastern Europe

Source: own elaboration.

Accordingly, higher concentrations of Supralocal Scale Euroregions are clearly shown in Central (39\%), Western (26\%) and North Europe (20\%). Conversely, Regional Scale Euroregions from the sample reflect a marked presence along the areas of South Western Europe (66\%), with a presence of this variant in the Central Mediterranean and Adriatic area (17\%) and one exception in Western Europe (17\%). Local Scale Euroregions seem to show a wider

4. However, the Catalogue also considered 19 Cross-Border Equipment and Trans-border Parks which are not included in this study. The numbers for the sample of 60 Euroregions have been adjusted accordingly in Table 4 . 
distribution across all areas. However, it is interesting to notice the lack of experiences in the sample for Central and Eastern Europe (0\%), where intermunicipal action is often favoured at supralocal scale. Indeed, the distribution of Euroregional variants across Europe seems to suggest that administrative traditions and historical factors have considerable meaning over Euroregional configurations. Germany's interest in pursuing good neighbourly relations since the aftermath of WWII, the Scandinavian tradition of cooperation in the Baltic area or even the integrative attitude of Benelux countries can all help to explain higher proliferation rates in those areas (Durà et al., 2018: 93-95). Likewise, the different degrees of administrative decentralisation opposed between two larger Northern and Southern European areas (Page and Goldsmith, 1987) also explain the higher presence of either S-Type (Northern) or R-Type (Southern Europe) Euroregions.

\section{Understanding the different territorial dynamics of cross-sea cooperation}

As hinted at the start of the article, the focus on cross-border maritime territories was mainly inspired by previous work on the subject (Camonita, 2019a, 2019b, forthcoming). However, such in-depth analysis suggested the identification of 'Eminently Maritime' territories with a stronger emphasis on the physical dimension of maritime borders than the one attempted in the Catalogue (Durà et al., 2018: 55-56). This was due to the fact that Euroregional organisations showing maritime or coastal borders (14 in our sample) do not necessarily focus on cross-sea cooperation in the presence of land borders among the parties involved. In other words, it is important to observe the difference between cross-border regions possessing maritime or coastal features and those where both the maritime border - and effective multi-sectoral cooperation of actors across it - are indeed the main concern of the CBC. Once the criteria were adjusted, only 6 cases in our sample could be defined as 'Eminently Maritime' Euroregions.

Furthermore, the application of 'proto-euroregional' theorisation to 'Eminently Maritime' territories allowed us to: $i$ ) highlight the low presence of crossborder governance organisations in these contexts when compared to the ones possessing land borders; ii) identify a group of INTERREG maritime areas that have never showed signs of Euroregional institutionalisation (Camonita, $2019 \mathrm{~b})$. The strong relationship between the two findings - in addition to the recognition of different territorial dynamics in cross-sea cooperation - bring us to consider a wider range of $\mathrm{CBC}$ activities in our analyses below.

As already suggested in our framework (MOT, 2019), maritime borders are very different from traditional land borders at both the geographical and administrative level. Therefore, our first empirical argument is derived from the observation of different patterns in CBC scale for "Eminently Maritime" activities both at Euroregional and 'proto-euroregional' level. Through applying this argument to the three modalities of the scale-based typology, Type $\mathrm{R}$ 
cooperation appears to be the easiest way to perform activities in a cross-border maritime space. By focusing on Type $\mathrm{R}$ partnerships made up of thematic networks pursuing common objectives (i.e. R\&D clusters), the interregional neighbourhood' modality allows for outcomes showing a looser territorial dimension and a major focus on common knowledge and practices. Conversely, Type L projects dedicated to 'proximity cooperation' would find it extremely hard to rely exclusively on local partnerships. This is because activities aimed at environmental protection and/or socioeconomic development of cross-border marine spaces and their surrounding areas would rather be oriented toward the 'intermediate borderlands' level (S Type) (i.e. environment, transport and mobility). Under these circumstances, projects aspiring towards a stronger territorial dimension will require partnerships with marked multilevel features. This is proved by the frequent involvement of a vast array of actors such as port authorities, territorial administrations with different levels of national authorizations regarding maritime and coastal competences, universities and technological centres, dedicated NGOs or even private stakeholders from the maritime industrial sector.

To support the discussion, Table 5 shows an analysis of $15 \mathrm{CBC}$ projects $(5$ for each territorial level) from 'Eminently Maritime' Euroregional and 'protoeuroregional' territories (Table 5). Apart from the 6 Euroregional projects in our sample, we also included 3 projects from the Sicily-Malta Cross-Border Region and 6 more from a previous list of 'proto-euroregional' areas (Camonita, 2019b). The analysis is based on matching the projects' territorial scale with the one from project-executing partnerships. Accordingly, it shows the regular presence of R-Type activities, the complete absence of exclusive Type L groupings of actors and the primacy of Type $S$ partnerships in cooperation activities with a stronger territorial impact (at both local and supralocal levels).

In terms of cross-border governance structures, our second argument derived from the observation of the six 'Eminently Maritime' Euroregions in our sample. The first striking feature is the immediate identification of all cases in the Supralocal Scale variant of the Euroregional model, with five Euroregions from the S (1) Multilevel Euroregion sub-typology and one S (2) Association of Municipalities (Table 6). This is followed by identification of the Euroregions geographical concentration along the maritime areas of Northern Europe. However, both conditions can be attributed to factors intrinsic to the geopolitical area. In geographical terms, the presence of the Baltic Sea in a context of Scandinavian cooperation would certainly encourage the development of cross-sea CBC experiences (Durà et al., 2018: 93-95; Perkmann, 2000, 2003, 2005). In administrative terms, there is a lack of strong regional authorities in Northern European countries and a corresponding weight of Northern provinces (Page and Goldsmith, 1987) even in cross-border activities. Notwithstanding, it is equally important to note that the examples provided do not exclude the opportunity for regional administrations in other parts of Europe to participate in new Euroregional proposals (i.e. Southern European regional authorities in the Mediterranean). 
Table 5. Analysis of 15 CBC projects according to the scale-based typology from 'Eminently Maritime' cross-border regions

\begin{tabular}{|c|c|c|c|c|}
\hline $\begin{array}{l}\text { CBC Project } \\
\text { Typology } \\
\text { (L-S-R) }\end{array}$ & Sources & $\begin{array}{l}\text { Interreg IV A } \\
\text { Programme (2007-2013) }\end{array}$ & Name of project (English) & Theme \\
\hline $\mathrm{S}$ & $\begin{array}{l}\text { Euroregional Catalogue: } \\
\text { Fehmarnbelt Committee }\end{array}$ & Fehmarnbelt Region & Futura Maritima & $\begin{array}{l}\text { Cohesion and } \\
\text { Social Integration }\end{array}$ \\
\hline $\mathrm{R}$ & $\begin{array}{l}\text { Euroregional Catalogue: } \\
\text { Baltic Euroregion }\end{array}$ & $\begin{array}{l}\text { South Baltic Cross-Border } \\
\text { Cooperation Programme }\end{array}$ & $\begin{array}{l}\text { DISKE- Development of Innovative } \\
\text { Systems through knowledge Exchange }\end{array}$ & $\begin{array}{l}\text { Research and } \\
\text { Investigation }\end{array}$ \\
\hline $\mathrm{S}$ & $\begin{array}{l}\text { Euroregional Catalogue: } \\
\text { Bothnian Arc }\end{array}$ & $\begin{array}{l}\text { Interreg Botnia /Atlantica } \\
\text { Kolarctic ENPI CBC }\end{array}$ & $\begin{array}{l}\text { ENERU- Efficient Energy Management } \\
\text { in Barents region }\end{array}$ & $\begin{array}{l}\text { Research and } \\
\text { Investigation }\end{array}$ \\
\hline $\mathrm{R}$ & $\begin{array}{l}\text { Euroregional Catalogue: } \\
\text { Finestlink Helsinki-Tallinna }\end{array}$ & Baltic Sea Region & Rail Baltica Growth Corridor & $\begin{array}{l}\text { Accessibility } \\
\text { and Transportation }\end{array}$ \\
\hline S & $\begin{array}{l}\text { Euroregional Catalogue: Greater } \\
\text { Copenhagen \& Skåne Committee }\end{array}$ & $\begin{array}{l}\text { Öresund - Kattegat - } \\
\text { Skagerrak }\end{array}$ & Oresund Region Creative Metropole & $\begin{array}{l}\text { Education } \\
\text { and culture }\end{array}$ \\
\hline S & $\begin{array}{l}\text { Euroregional Catalogue: Kvarken } \\
\text { Council }\end{array}$ & Botnia Atlantica & Kvarken Short Cut System & $\begin{array}{l}\text { Accessibility } \\
\text { and Transportation }\end{array}$ \\
\hline L & $\begin{array}{l}\text { Sicily-Malta Cross-Border Region } \\
\text { ('proto-euroregional') }\end{array}$ & Italy-Malta & $\begin{array}{l}\text { CALYPSO - Radar Monitoring System and } \\
\text { Response against Marine Oil Spills in the } \\
\text { Malta Channel }\end{array}$ & $\begin{array}{l}\text { Energy and } \\
\text { Environment }\end{array}$ \\
\hline S & $\begin{array}{l}\text { Sicily-Malta Cross-Border Region } \\
\text { ('proto-euroregional') }\end{array}$ & Italy-Malta & $\begin{array}{l}\text { SIMIT - Integrated System of Cross-Border } \\
\text { Civil Protection }\end{array}$ & $\begin{array}{l}\text { Energy and } \\
\text { Environment }\end{array}$ \\
\hline $\mathrm{R}$ & $\begin{array}{l}\text { Sicily-Malta Cross-Border Region } \\
\text { ('proto-euroregional') }\end{array}$ & Italy-Malta & $\begin{array}{l}\text { IMAGENX - Italia Malta Genome Breast } \\
\text { Cancer Border Risk Surveillance }\end{array}$ & Health \\
\hline $\mathrm{L}$ & INTERREG Maritime Areas & Italy- France Maritime & $\begin{array}{l}\text { GIONHA - Governance and Integrated } \\
\text { Observation on Marine Natural Habitat }\end{array}$ & $\begin{array}{l}\text { Energy and } \\
\text { Environment }\end{array}$ \\
\hline $\mathrm{L}$ & INTERREG Maritime Areas & Greece-Cyprus & $\begin{array}{l}\text { Configuration and Pilot Implementation Plans } \\
\text { Integrated Coastal Zone Management in } \\
\text { Rhodes and Cyprus }\end{array}$ & $\begin{array}{l}\text { Spatial Planning } \\
\text { (Maritime) }\end{array}$ \\
\hline L & INTERREG Maritime Areas & Ireland-Wales & CSTP - Celtic Sea Trout Project & $\begin{array}{l}\text { Energy and } \\
\text { Environment }\end{array}$ \\
\hline $\mathrm{L}$ & INTERREG Maritime Areas & Greece-Italy & $\begin{array}{l}\text { DEMSNIISI - Stations Network on the Ionian } \\
\text { Islands and Southern Italy }\end{array}$ & $\begin{array}{l}\text { Energy and } \\
\text { Environment }\end{array}$ \\
\hline $\mathrm{R}$ & INTERREG Maritime Areas & 2 Seas & $\begin{array}{l}\text { AIMER - Achieving the Integration of Migrant } \\
\text { communities and Ethnic Residents }\end{array}$ & $\begin{array}{l}\text { Cohesion and } \\
\text { Social Integration }\end{array}$ \\
\hline $\mathrm{R}$ & INTERREG Maritime Areas & $\begin{array}{l}\text { Northern Ireland - Ireland - } \\
\text { Scotland }\end{array}$ & $\begin{array}{l}\text { BioMara- Sustainable Fuels from Marine } \\
\text { Biomass }\end{array}$ & $\begin{array}{l}\text { Energy and } \\
\text { Environment }\end{array}$ \\
\hline
\end{tabular}




\begin{tabular}{|c|c|c|c|}
\hline Brief description & $\begin{array}{l}\text { Partnership } \\
\text { typology } \\
\text { (L-S-R) }\end{array}$ & Partnership composition (type of organisation) & Budget $(€)$ \\
\hline $\begin{array}{l}\text { Info \& professional training for young people in the mari- } \\
\text { time sector industry }\end{array}$ & $\mathrm{S}$ & $\begin{array}{l}2 \text { Professional Schools; } 1 \text { NG0; } 1 \text { Leisure and Education } \\
\text { Centre; }\end{array}$ & 778,886 \\
\hline $\begin{array}{l}\text { Cooperation and exchanges of technology parks and } \\
\text { SME incubators }\end{array}$ & $\mathrm{R}$ & $\begin{array}{l}1 \text { Local Council; } 3 \text { Innovation, Science and Technology Cen- } \\
\text { tres; } 1 \text { Public Enterprise; }\end{array}$ & $1,315,311$ \\
\hline $\begin{array}{l}\text { Joint studies and exchange of practices in energy } \\
\text { management }\end{array}$ & $\mathrm{S}$ & $\begin{array}{l}1 \text { University; } 1 \text { Technology Center; } 1 \text { Private Enterprise; } 1 \\
\text { Local Council, } 1 \text { Euroregion (Bothnian Arc); } 1 \text { Municipal Edu- } \\
\text { cation and Training Consortium; *1 Intermunicipal Association } \\
\text { (Russia) }\end{array}$ & 944,324 \\
\hline $\begin{array}{l}\text { Study for development of multimodal logistics and } \\
\text { modern railway infrastructure in Eastern Baltic Sea } \\
\text { Region }\end{array}$ & $\mathrm{R}$ & $\begin{array}{l}8 \text { Local Councils; } 5 \text { Regional Councils, } 2 \text { Provincial councils; } \\
3 \text { Universities; } 2 \text { Technology Centres; } 1 \text { Regional agency } \\
\text { (includes extra-Euroregional actors) }\end{array}$ & $3,587,090$ \\
\hline $\begin{array}{l}\text { Developing strategies and competences for innovative } \\
\text { cultural platforms }\end{array}$ & $\mathrm{S}$ & 13 Local Councils; 3 Universities & $1,870,949$ \\
\hline $\begin{array}{l}\text { Assessment and impact study of Euroregional infras- } \\
\text { tructure on a number of sectors, plus investigation on } \\
\text { new fixed links }\end{array}$ & S & 1 Euroregion (Kvarken Council); 1 Regional Council & $1,100,000$ \\
\hline $\begin{array}{l}\text { Set-up of a cross-border environmental monitoring } \\
\text { system for the detection of oil spillages in the border } \\
\text { marine space }\end{array}$ & S & $\begin{array}{l}3 \text { Universities; } 3 \text { Regional Agencies; } 1 \text { Civil Protection } \\
\text { Department; } 1 \text { Armed Forces Representation (Malta) }\end{array}$ & $1,455,399$ \\
\hline $\begin{array}{l}\text { Development of a coordinated cross-border civil pro- } \\
\text { tection plan between the two islands in case of natural } \\
\text { disaster }\end{array}$ & $\mathrm{S}$ & $\begin{array}{l}3 \text { Universities; } 1 \text { Regional Government; } 2 \text { Civil Protection } \\
\text { departments }\end{array}$ & $2,369,589$ \\
\hline $\begin{array}{l}\text { Consolidation of a cross-border research network dea- } \\
\text { ling with breast cancer research }\end{array}$ & $\mathrm{R}$ & $\begin{array}{l}2 \text { Universities; } 1 \text { Hospital; } 1 \text { Provincial department; } 1 \text { National } \\
\text { council for Science \& Technology }\end{array}$ & $2,406,710$ \\
\hline $\begin{array}{l}\text { Protection, enhancement of marine resources and } \\
\text { awareness raising of marine habitats that support the } \\
\text { local area of the Pelagos Sanctuary }\end{array}$ & $\mathrm{S}$ & $\begin{array}{l}2 \text { Regional governments; } 2 \text { Regional Agencies; } 1 \text { Provincial } \\
\text { government }\end{array}$ & $2,465,000$ \\
\hline $\begin{array}{l}\text { Feasibility study for a joint analysis of coastal areas and } \\
\text { promotion of common measures towards integrated } \\
\text { coastal and marine management }\end{array}$ & $\mathrm{S}$ & 1 Local Council; 1 University; 2 Research Centres & 700,000 \\
\hline $\begin{array}{l}\text { Joint study to monitor, manage \& protect sea trout in } \\
\text { the coastal rivers of the region \& the Irish Sea itself. } \\
\text { Implications for fisheries and cross-border biodiversity. }\end{array}$ & $\mathrm{S}$ & $\begin{array}{l}2 \text { Universities; } 1 \text { Public Environment Agency, } 1 \text { National } \\
\text { agency }\end{array}$ & $2,081,841$ \\
\hline $\begin{array}{l}\text { Development of a network of } 11 \text { meteorological } \\
\text { ground-based stations }\end{array}$ & $\mathrm{S}$ & $\begin{array}{l}1 \text { Technology Centre, } 1 \text { University, } 1 \text { Regional government, } 1 \\
\text { Provincial government }\end{array}$ & 759,500 \\
\hline $\begin{array}{l}\text { Creation of a model approach to assist local areas } \\
\text { across the cross-border zone to integrate ethnic } \\
\text { minorities of migrants }\end{array}$ & $\mathrm{R}$ & 2 Provincial Councils, 1 Private services business; 3 NGOs; & $2,468,403$ \\
\hline $\begin{array}{l}\text { Feasibility study for production of mari-fuels from marine } \\
\text { biomass derived from seaweeds and microalgal sources } \\
\text { as an alternative to agri-fuels production }\end{array}$ & $\mathrm{R}$ & $\begin{array}{l}1 \text { NGO, } 2 \text { Universities, } 2 \text { Institutes of Technology, } 1 \text { Research } \\
\text { Centre }\end{array}$ & $4,874,414$ \\
\hline
\end{tabular}

Source: Durà et al. (2018); Camonita (2019b); Keep.eu. 
Table 6. Identification of 6 'Eminently Maritime' Euroregions in the sample

\begin{tabular}{|c|c|c|c|c|c|c|c|c|}
\hline Model Variants & $\begin{array}{c}\text { Total of } 6 \\
\text { Euroregions }\end{array}$ & Sub-total & $\begin{array}{l}\text { Approx. size } \\
\text { I intervals }\end{array}$ & $\begin{array}{l}\text { Euroregion } \\
\text { typology }\end{array}$ & $\begin{array}{l}\text { Institutional } \\
\text { density }\end{array}$ & $\begin{array}{l}\text { Level of self- } \\
\text { government }\end{array}$ & $\begin{array}{l}\text { - CBC Project } \\
\text { Scale (no. 61) }\end{array}$ & Euroregions \\
\hline \multirow{5}{*}{$\begin{array}{l}\text { (S) SUPRALOCAL } \\
\text { SCALE EUR }\end{array}$} & \multirow[t]{5}{*}{6} & \multirow[t]{2}{*}{5} & \multirow{2}{*}{$\begin{array}{l}\text { From } 950 \text { to } \\
55,000 \mathrm{~km}^{2}\end{array}$} & \multirow{2}{*}{$\begin{array}{l}\text { S (1): Multilevel } \\
\text { Euroregion } \\
\text { (Eurodistrict, } \\
\text { Eurometropolis) }\end{array}$} & 3 to 10 & \multirow{2}{*}{$\begin{array}{l}\text { From local } \\
\text { to regional }\end{array}$} & \multirow[t]{2}{*}{$\mathrm{S} \times 4(\mathrm{R} \times 2)$} & S1: Bothnian Arc, Kvarken \\
\hline & & & & & 11 to 30 & & & $\begin{array}{l}\text { Council, Fehmarnbelt } \\
\text { Commitee, FinEst Link; } \\
\text { Baltic Euroregion }\end{array}$ \\
\hline & & \multirow[t]{3}{*}{1} & & \multirow{3}{*}{$\begin{array}{l}\text { S (2): Association } \\
\text { of Municipalities }\end{array}$} & 2 & \multirow{3}{*}{$\begin{array}{l}\text { Local and } \\
\text { supralocal }\end{array}$} & & \multirow{3}{*}{$\begin{array}{l}\text { S2: Greater Copenhagen } \\
\text { \& Skane Committee }\end{array}$} \\
\hline & & & & & 3 to 10 & & & \\
\hline & & & & & More than 30 & & & \\
\hline
\end{tabular}

Source: Own elaboration.

Two further considerations reinforce our discussion on 'Eminently Maritime' Euroregions. Firstly, the predominance of the Supralocal Scale and of the $S$ (1) Multilevel Euroregion is deeply intertwined with the territorial dynamics of cross-sea cooperation outlined above. ${ }^{5}$ Secondly, the six units from the sample clearly show high levels of institutionalisation and a common strategic behaviour (i.e. publication of joint material dedicated to visions, operational documents, cross-border strategies, etc.) as expected by our sources in the framework (MOT, 2019). On the one hand, such dedication reinforces the political commitment of areas where maritime borders do not make CBC an immediate necessity. On the other, the lack of sufficient involvement would in part explain the recurring presence of maritime territories possessing an INTERREG programme and yet do not show a corresponding Euroregional platform. A lack of political will keeps them locked in a 'proto-euroregional' state (Camonita, 2019b). In conclusion, empirical observations allow us to confirm that multisectoral CBC across a maritime border: $i$ ) will necessarily need to rely on multilevel S-Type and R-Type partnerships at all level of activities (L-S-R); and that ii) existing cross-border governance systems in these areas show a tendency to adopt the S (1) Multilevel Euroregion modality for actor-inclusive and strategic forms of cooperation.

\section{Conclusion}

This article has attempted to advance the theoretical debate on Euroregions by focusing on their governance structures and the territorial scale of their activities. The main theoretical propositions included: $i$ ) a scale-based typology for the classification of cross-border INTERREG projects (Local, Eminently Supralocal, Regional) and of the partnerships executing them; ii) a Euroregional model based on three model variants (Local, Supralocal, Regional) and on six-sub

5. Speculation may lead us to assume that the only S (2) intermunicipal exception (Greater Copenhagen \& Skåne Committee) may be justified by the presence of important crossborder infrastructure (Øresund Bridge), thus overriding the separating effect of the maritime border and shifting the focus on other terrestrial priorities. 
typologies for the classification of existing Euroregions (ranging from 'bilateral Eurocities' to 'multiregional Euroregions'); and iii) a contextualised discussion on the different territorial dynamics of CBC in 'Eminently Maritime' cross-border territories (and the effective multi-sectoral cooperation of actors across it).

In the last part of this article, we will provide some final considerations on the results of the research. First, the creation of a scale-based typology for $\mathrm{CBC}$ activities was considered as an inclusive method for framing all types of cooperation modalities. Rather than considering this research as a way to discover the best $\mathrm{CBC}$ across Europe's borders, the article defends the concept that each territorial scale and Euroregional model variant holds a separate territorial dimension. In turn, each individual one leads to considerable variation in the activities performed.

Notwithstanding, the research was also able to highlight a tendency among the most performing Euroregions to prefer the Supralocal Scale in their governance structure. It also confirmed a few interesting exceptions for S-Type Euroregions to extend their territorial reach and to perform special interventions at other levels. While this can certainly be explained by historical factors and administrative traditions in different parts of Europe (Durà et al., 2018; Perkmann, 2000; Page and Goldsmith, 1987), it is also important to consider that the most employed sub-typology in the sample was the S (1) Multilevel Euroregion (27/60). This leads us to suggest that in the presence of a strategic interest for CBC with a stronger territorial impact (L or S Type), it may be favourable to consider employing an S (1) modality. Given the difficulties of intermunicipal action in countries with more centralised administrative traditions (i.e. Italy, Spain), the inclusive nature of multilevel governance would allow for a combination of competent regional administrations and the membership of local and supralocal actors (i.e. local councils, provinces, research centres, etc.) to perform a lobbying function despite the limited responsibilities. In turn, this may help quell suspicions over autonomist or separatist tendencies (Perkmann, 2000, 2003, 2005). Moreover, it would transmit the image of Euroregions as soft spaces and examples of institutional entrepreneurship for policy formulation and implementation scenarios (Miörner et al., 2018; Telle, 2017; Perkmann and Spicer, 2007).

Meanwhile, in the second part of the article our results hinted towards the need for a S (1) Multilevel Euroregion framework for 'Eminently Maritime' territories. This was demonstrated by the interpretation of maritime CBC through our scale-based typology. In this regard, the typology has shown the need to employ Type $S$ and $R$ partnerships at all levels even when the projects are focused on the local scale. Likewise, observation of the governance structures in the six 'Eminently Maritime' Euroregions in our sample also supported our discussion. By reconnecting to arguments in our framework (MOT, 2019), both the wider separating effect generated by maritime spaces and the presence of a vast array of actors with different competences in relation to cross-sea activities are elements to be strongly considered in "Eminently Maritime" processes of Euroregional institutionalisation. 
Finally, in terms of research prospects, two paths may indicate the way toward future contributions. First, the territorial scale-based typology could be further tested by expanding the number of Euroregions in the sample. In turn, this could lead to new cross-data analysis of sectoral data (i.e. fields of activity, categorisations of project outputs, etc.). Second, the features uncovered in maritime borders could inspire new studies based on different geographical backgrounds. Accordingly, the methodology may be adjusted for understanding $\mathrm{CBC}$ across other non-plain or non-easily commutable borders (i.e. mountainous or fluvial/lake areas). From our perspective, the increased presence of large-scale and sectoral comparative studies will be key to understanding cross-border governance dynamics in Europe.

\section{Bibliographical references}

Association of European Border Regions (AEBR) (2000). Practical guide to crossborder cooperation ( $3^{\text {rd }} \mathrm{ed}$.). Retrieved from <http://www.aebr.eu/files/publications/ lace_guide.en.pdfs

Boman, Julia and BerG, Eiki (2007). "Identity and institutions shaping cross-border co-operation at the margins of the European Union". Regional and Federal Studies, 17 (2), 195-215. <https://doi.org/10.1080/13597560701318516>

CAmonita, Francesco (2019a). "Envisioning the Sicilian-Maltese archipelago: A Braudelian inspired triple-level analysis of a European cross-border region". Island Studies Journal, 14 (1), 125-146.

- (2019b). "Going through the 'proto-euroregional' stage: The case of the SicilyMalta cross-border region". Sud-Ouest Européen, 48, 133-147

- (forthcoming). "Cross-border islands governance: A field analysis of the Italy-Malta Interreg Programme". In: Dupeyron Bruno; Payan Toni and Noferini Andrea (eds.). Agents and structures in cross-border governance: Comparing North America and Europe in an era of border securitization. Toronto: Toronto University Press.

Carming, Joann; Hicks, Barbara and Beckmann, Andreas (2003). "Leveraging local action: Grassroots initiatives and transboundary collaboration in the formation of the White Carpathian Euroregion". International Sociology, 18 (4), 703-725. $<$ https://doi.org/10.1177/0268580903184004>

CARneiro, Gonçalo et al. (2017). Cross-border cooperation in maritime spatial planning. European Commission report. $<$ https://doi.org/10.2826/28939>

Conference of Peripheral and Maritime Regions (CPMR) (2018). The future of INTERREG: 10 messages from the CPMR. Technical Note. Retrieved from $<$ https://cpmr.org/wpdm-package/the-future-of-interreg-10-messages-from-thecpmr/?wpdmdl=17990\&ind $=1529396962494>$

Decoville, Antoine; Durand, Frédéric and Feltgen, Valérie (2015). Opportunities of cross-border cooperation between small and medium cities in Europe. LISER report by the Spatial Development Observatory (Luxembourg). Retrieved from <https:// ec.europa.eu/futurium/en/system/files/ged/opportunities_of_crossborder_cooperation_between_small_and_medium_cities_in_europe.pdf $\mathrm{s}$

Durà, Antoni; Berzi, Matteo; Camonita, Francesco and Noferini, Andrea (2019). "Ablandando fronteras: un análisis de las eurorregiones en la Unión 
Europea”. In: Farinós, Joaquín; Ojeda, Juan Francisco and Trillo, Juan Manuel (eds.). España: Geografías de un estado posmoderno. Madrid/Barcelona: AGE/Geocrítica, 219-232. Retrieved from <http://www.ub.edu/geocrit/estadoposmoderno.pdf>

DurÀ, Antoni; Camonita, Francesco; Berzi, Matteo and Noferini, Andrea (2018). Euroregions, excellence and innovation across EU borders: A catalogue of good practices. Barcelona: Department of Geography, UAB. Retrieved from < https://ddd.uab.cat/ pub/llibres/2018/189399/RECOT_CRII_Catalogue.pdf>

FALUd, Andreas (2013). "Territorial cohesion, territorialism, territoriality; soft planning: A critical review”. Environment; Planning A, 45, 1302-1317. <https://doi.org/10.1068/a45299>

Fricke, Carola (2015). "Spatial governance across borders revisited: Organizational forms and spatial planning in metropolitan cross-border regions". European Planning Studies, 23 (5), 849-870. $<$ https://doi.org/10.1080/09654313.2014.887661>

Gasparini, Alberto (2014). "The Euroregion as an institutional technology for planning and managing the cross-border cooperation". Teorija In Praksa, 51, 262-284. Retrieved from <https://www.dlib.si/stream/URN:NBN:SI:DOC-ZNI6K8PW/ ef635a0e-2885-429c-b564-585957f6fa4c/PDF>

Gasparini, Alberto and Del Bianco, Daniele (2011). Strategies and Euroregions for cross-border co-operation in Balkan and Danube European countries. Gorizia: Grafica Goriziana (Gorizia-I). Retrieved from <http://isig.it/wp-content/uploads/2012/11/ SWOT-Strategies-and-Euroregions-for-CBC.pdf>

Giband, David and Vicente, Joan (2018). "Los espacios transfronterizos europeos: ¿un objeto geográfico de difícil definición? Una aproximación desde la perspectiva de los soft spaces". Documents d'Anàlisi Geogràfica, 64 (3), 421-441. $<$ https://doi.org/10.5565/rev/dag.520>

Glinos, Irene and Wismar, Matthias (eds.) (2013). Hospitals and borders: Seven case studies on cross-border collaboration and health system interactions. World Health Organization Regional Office for Europe. Retrieved from <http://www.euro.who. int/_data/assets/pdf_file/0019/233515/e96935.pdf?ua=1>

Gualini, Enrico (2003). "Cross-border governance: Inventing regions in a transnational multi-level polity”. DisP - The Planning Review, 39 (152), 43-52. <https://doi.org/10.1080/02513625.2003.10556833>

Halleux, Vivienne (2019). European territorial cooperation (Interreg) 20212027. European Parliamentary Research Service, PE 628.228. Retrieved from <http:/www.europarl.europa.eu/RegData/etudes/BRIE/2018/628228/EPRS_ BRI(2018)628228_EN.pdf>

Harguindéguy, Jean-Baptiste and Bray, Zoé (2009). "Does cross-border cooperation empower European regions? The case of Interreg III-A France-Spain". Environment and Planning C: Politics and Space, 27 (4), 747-760. <https://doi.org/10.1068/c08119>

Harguindéguy, Jean-Baptiste and SÁnchez, Almudena (2017). "European crossborder regions as policy-makers: A comparative approach". Journal of Borderlands Studies, 32 (2), 1-17. <https://doi.org/10.1080/08865655.2016.1195706>

HILl, Richard and KRING, Katerina (2013). European territorial co-operation maritime cross-border programmes: The maritime dimension. INTERACT final report. Retrieved from <http:/www.interact-eu.net/download/file/fid/1186> 
Hooghe, Liesbet and Marks, Gary (2001). Multi-level governance and European integration. Lanham (US): Rowman \& Littlefield..

LEPIK, Katri-Liis (2009). "Euroregions as mechanisms for strengthening cross-border cooperation in the Baltic Sea Region". TRAMES: A Journal of the Humanities and Social Sciences, 13 (3), 265-284. <https://doi.org/10.3176/tr.2009.3.05>

LePiK, Katri-Liis and Krigul, Merle (2014). "Challenges in knowledge sharing for innovation in cross-border context". International Journal of Knowledge-Based Development 5 (4), 332-342. <https://doi.org/10.1504/IJKBD.2014.068044>

LundQuist, Karl-Johan and TrIPPL, Michaela (2013). "Distance, proximity and types of cross-border innovation systems: A conceptual analysis”. Regional Studies, 47 (3), 450-460. <http://dx.doi.org/10.1080/00343404.2011.560933>

Medeiros, Eduardo (2011). "(Re)defining the Euroregion concept". European Planning Studies, 19 (1), 141-158. <http://doi.org/10.1080/09654313.2011.531920>

- (2013). "Euro-Meso-Macro: The new regions in Iberian and European space". Regional Studies, 47 (8), 1249-1266. <http://doi.org/10.1080/00343404.2011.602336>

Miörner, Johan; Zukauskaite, Elena; Trippl, Michaela and Moodysson, Jerker (2018). "Creating institutional preconditions for knowledge flows in crossborder regions". Environment and Planning C: Politics and Space, 36 (2), 1-18. <https://doi.org/10.1177/2399654417704664>

Mission Opérationnelle Transfrontalière (MOT). (2019). Cross-Border Maritime Cooperation. Retrieved from <http://www.espaces-transfrontaliers.org/en/ resources/topics-of-cooperation/themes/theme/show/cross-border-maritime-cooperation/> [last consulted: 28/02/19]

Morata, Francesc (2007). "La costruzione istituzionale delle Euroregioni". Le Istituzioni Del Federalismo, 7, 7-39. Retrieved from <https:/www.regione.emilia-romagna.it/affari_ist/supplemento_4_07/Morata.pdf>

Morata, Francesc and Cots, Francesc (2006). A sustainable development strategy for the Pyrenees Mediterranean Euroregion: Basic guidelines. Instituto Universitario de Estudios Europeos, UAB Barcelona. Consell Assessor de Desenvolupament Sostenible de la Generalitat de Catalunya. Retrieved from <https://ddd.uab.cat/record/102084>

Morata, Francesc and Noferini, Andrea (2013). "The Pyrenees-Mediterranean Euroregion: Policy networks and institutional capacities". In: Bellini, Nicola and HilPERT, Ulrich (eds.). Europe's changing geography as a result of trans-regional cooperation. Abingdon, UK: Routledge, eBook.

Noferini, Andrea; Berzi, Matteo; Camonita, Francesco and Durà, Antoni (2020). "Cross-border cooperation in the EU: Euroregions amid multilevel governance and re-territorialization”. European Planning Studies, 28 (1), 35-56

Oliveras, Xavier; Durà, Antoni and Perkmann, Markus (2010). "Las regiones transfronterizas: Balance de la regionalización de la cooperación transfronteriza en Europa (1958-2007)". Documents d'Anàlisi Geogràfica, 56 (1), 21-40.

Organisation for Economic Co-Operation and Development (2010). "The interface between subnational and national levels of government". In: Better regulation in Europe: Denmark 2010. OECD online reports, 169-174. <https://doi.org/10.1787/9789264084551-en> 
Page, Edward and Goldsmith, Michael (1987). Central and local government relations. Beverly Hills, CA: Sage.

Perkmann, Markus (1999). "Building governance institutions across European borders". Regional Studies, 33 (7), 657-667. <https://doi.org/10.1080/00343409950078693>

- (2000). Euroregions: strategies of institution-building in the new European polity. Thesis submitted for the degree of PhD. Lancaster University, Department of Sociology.

- (2002). "Euroregions: Institutional entrepreneurship in the European Union". In: Perkmann, Markus and Sum, Gai-Ling (eds.). Globalization, regionalization and cross-border regions. London: Palgrave Macmillan UK, 103-124.

- (2003). "Cross Border Regions in Europe. Significance and Drives of Regional CrossBorder Co-Operation”. European Urban and Regional Studies, 10 (2), 153-171. <https://doi.org/10.1177/0969776403010002004>

- (2005). "Cross-border co-operation as policy entrepreneurship: explaining the variable success of European cross-border regions". CSGR Working Paper, 166 (5), 32. Retrieved from <http://wrap.warwick.ac.uk/1953/1/WRAP_Perkmann_wp16605.pdf>

Perkmann, Markus and Spicer, André (2007). "Healing the scars of history': Projects, skills and field strategies in institutional entrepreneurship". Organization Studies, 28 (7), 1101-1122. <https://doi.org/10.1177/0170840607078116>

PERrin, Thomas (2013). Culture et Eurorégions. La coopération culturelle entre régions européennes. Brussels: Éditions de l'Université de Bruxelles.

Piattoni, Simona (2010). The theory of multi-level governance: conceptual, empirical, and normative challenges. Oxford: Oxford University Press.

Popescu, Gabriel (2008). "The conflicting logics of cross-border reterritorialization: Geopolitics of Euroregions in Eastern Europe”. Political Geography, 27 (4), 418-438. <https://doi.org/10.1016/j.polgeo.2008.03.002>

SANGuin, André-Louis (2013). "Euroregions and other EU's cross-border organizations: the risk of confusion, redundancy, oversizing and entropy. A critical assessment”. ANNALES: Series Historia et Sociologia, 23 (1), 155-164. Retrieved from <http://classiques.uqac.ca/contemporains/sanguin_andre_louis/articles/ Euroregions_and_Other_EU_cross-borders/Euroregions_URN_NBN_SI_DOCCH9SLVPB.pdf>

Schaefer Nicole and Barale, Vittorio (2011). "Maritime spatial planning: Opportunities \& challenges in the framework of the EU integrated maritime policy". Journal of Coastal Conservation, 15 (2), 237-245. <https://doi.org/10.1007/s11852-011-0154-3>

Telle, Stephan (2017). "Euroregions as soft spaces: Between consolidation and transformation”. European Spatial Research and Policy, 24 (2), 93-110. <https://doi.org/10.1515/esrp-2017-0011>

TrIPPL, Michaela (2010). "Developing cross-border regional innovation systems: Key factors and challenges". Tijdschrift voor Economische en Sociale Geografie, 101 (2), 150-160. $<$ https://doi.org/10.1111/j.1467-9663.2009.00522.x>

Wassenberg, Birte; Reitel, Bernard; Peyrony, Jean and Rubió, Jean (2015). Territorial cooperation in Europe $-A$ historical perspective. Luxemburg: Publications Office of the European Union, 172 p. Retrieved from: <https://ec.europa.eu/futurium/ en/system/files/ged/interreg_25years_en.pdf> 
Weidenfeld, Adi (2013). "Tourism and Cross-Border Regional Innovation Systems". Annals of Tourism Research, 42, 191-213. $<$ http://dx.doi.org/10.1016/j.annals.2013.01.003>

Zimmerbauer, Kaj (2011). "Conceptualizing borders in cross-border regions: Case studies of the Barents and Ireland-Wales Supranational Regions". Journal of Borderlands Studies, 26 (2), 211-229.

$<$ http://dx.doi.org/10.1080/08865655.2011.641322> 